\title{
Comparative studies on [Pasteurella] testudinis and $[P$.] testudinis-like bacteria and proposal of Chelonobacter oris gen. nov., sp. nov. as a new member of the family Pasteurellaceae
}

\author{
Rikke Heidemann Gregersen, ${ }^{1}$ Claudia Neubauer, ${ }^{2}$ Henrik Christensen, ${ }^{1}$ \\ Anders Miki Bojesen, ${ }^{1}$ Michael $\mathrm{Hess}^{2}$ and Magne Bisgaard ${ }^{1}$ \\ ${ }^{1}$ Department of Veterinary Pathobiology, Faculty of Life Sciences, University of Copenhagen, \\ DK, 1870 Frederiksberg C, Denmark \\ ${ }^{2}$ Department for Farm Animals and Herd Management, Clinic for Avian, Reptile and Fish Medicine, \\ University of Veterinary Medicine Vienna, Veterinaerplatz 1, 1210 Vienna, Austria
}

Correspondence

Rikke Heidemann Gregersen cava@dsr.life.ku.dk

\begin{abstract}
A collection of 12 strains, isolated from diseased tortoises and tentatively identified as [Pasteurella] testudinis-like based on phenotypic characters, was compared with three reference strains of $[P$.] testudinis. All strains could be separated from the reference strains with respect to $16 \mathrm{~S}$ rRNA gene sequences, partial sequences of the rpoB housekeeping gene and by phenotypic characters. Based upon differences in 16S rRNA and rpoB gene sequences, the new isolates are suggested to represent a novel species in a new genus of the family Pasteurellaceae Pohl 1981, for which the name Chelonobacter oris gen. nov., sp. nov. is proposed. The type strain is $1662^{\top}$ $\left(=\mathrm{CCUG} 55632^{\top}=\mathrm{DSM} 21392^{\top}\right) . \beta$-Haemolysis and acid production from $(+)$-L-arabinose, dulcitol, (-)-D-mannitol, (+)-D-mannose, trehalose and salicin separated the new strains from members of existing genera of the family Pasteurellaceae, in addition to the $\beta$-galactosidase, urease and $\alpha$-glucosidase reactions. Differences in indole production, phosphatase, $\beta$ glucosidase and production of acid from dulcitol and trehalose separated C. oris from [P.] testudinis. Several phenotypic characters separated C. oris from Bisgaard's taxa 14 and 32.
\end{abstract}

A Pasteurella species subsequently classified as [Pasteurella] testudinis was consistently found to be associated with respiratory lesions in captive tortoises with signs of respiratory disease (Snipes \& Biberstein, 1982). Previously, phenotypically related isolates have been found to be part of the gastrointestinal and nasal flora of healthy tortoises (Snipes et al., 1980), indicating a commensal inhabitance of the mucosal membrane of the respiratory and alimentary tract with possible opportunistic pathogenic capabilities (Jang \& Biberstein, 1991). The collection

The GenBank/EMBL/DDBJ accession numbers for the $16 \mathrm{~S}$ rRNA gene sequences of strains $1662^{\top}, 8484,17123$ and 18043 are EU331064, EU331065, EU331067 and EU331066, respectively; those for the rpoB gene sequences of strains $11321,18043,8484,17123,4 \mathrm{n}$ and 770 are EU331069, EU331070, EU331068, EU331073, EU331072 and EU331071, respectively.

Phylogenetic relationships between Chelonobacter oris gen. nov., sp. nov. and strains related to [Pasteurella] testudinis based on maximumlikelihood analysis of rpoB sequences (Fig. S1), a photomicrograph of Chelonobacter oris strain $1662^{\top}$ after cultivation in brain-heart infusion broth (Fig. S2) and characteristics for differentiation of genera within the family Pasteurellaceae (Table S1) are available with the online version of this paper. of strains investigated by Snipes \& Biberstein (1982) showed a significant degree of phenotypic diversity. Based on DNA-DNA hybridization data, Mutters et al. (1985) excluded [P.] testudinis from the genus Pasteurella sensu stricto. Subsequent studies of the 16S rRNA gene sequence-based phylogeny of the family Pasteurellaceae showed that $[P$.] testudinis formed a separate cluster, which branched deeper than all previously described taxa within the family (Dewhirst et al., 1993). Finally, Christensen et al. (2003) reported that the avian taxa 14, 32 and 40 of Bisgaard were phylogenetically related to $[P$.] testudinis.

The aims of the present study were to characterize a collection of strains from tortoises that had been tentatively identified as $[P$.] testudinis and to evaluate the taxonomy of these organisms within the family Pasteurellaceae. Classification was based mainly on sequencing of $16 \mathrm{~S}$ rRNA and $r p o B$ genes. $r p o B$ gene sequence-based classification has been used previously with the family Pasteurellaceae (Angen et al., 2003; Korczak et al., 2004). In addition, this gene has been recommended as one of the genes suitable for DNA sequence-based identification in cases where phenotypic identification is difficult (Christensen et al., 2007). 
A total of 15 strains, 12 unclassified isolates from clinically affected tortoises and turtles and three reference strains of $[P$.] testudinis, including the type strain, was investigated (Table 1). The three reference strains were included in the original study on the classification of [P.] testudinis (Snipes \& Biberstein, 1982). Unclassified isolates were originally classified as haemolytic members of the family Pasteurellaceae based upon colony morphology, Gram staining, motility tests, catalase and oxidase activities, and fermentative catabolism of glucose in Hugh and Leifson's medium (Bisgaard et al., 1991).

Sequencing of the $16 \mathrm{~S}$ rRNA genes of strains $1662^{\mathrm{T}}, 8484$, 17123 and 18043 was performed according to previous reports (Angen et al., 2003; Christensen et al., 2002). Accession numbers for the 16S rRNA gene sequences of the above-mentioned strains are given in Table 1 and Fig. 1.

A BLAST search (Altschul et al., 1997) of GenBank (Benson et al., 2006) was performed. Pairwise comparisons for similarity were performed by the program WATER included in EMBOss (Rice et al., 2000). Multiple alignment was performed by CLUSTAL_X (Thompson et al., 1997). Maximum-likelihood analysis including bootstrap analysis was performed by FASTDNAML (Felsenstein, 1995; Olsen et al., 1994) on a Linux 7.2-compatible server. The analysis was run with a transition/transversion ratio of 1.5.

The three strains $1662^{\mathrm{T}}, 8484$ and 18043 formed a monophyletic group in the $16 \mathrm{~S}$ rRNA gene sequence analysis with $100 \%$ bootstrap support; $99.9 \%$ similarity was observed between strains $1662^{\mathrm{T}}$ and 8484 and $98.6 \%$ between strains $1662^{\mathrm{T}}$ and 18043 . The group was only distantly related to other members of the family Pasteurellaceae (Fig. 1). Taxa 14 and 32, as well as [P.] testudinis CCUG $19802^{\mathrm{T}}$ and strain 17123 , were the most closely related, although the relationship was poorly defined and without bootstrap support. The highest sequence similarity $(93.3 \%)$ to the group of strains $1662^{\mathrm{T}}, 8484$ and 18043 was observed with strain 17123 , whereas $92.9 \%$ similarity was observed with the type strain of $[P$.] testudinis and with taxa 14 and 32. Since the $16 \mathrm{~S}$ rRNA gene sequence similarities are predominantly below approximately $95 \%$ between genera of the family Pasteurellaceae (Christensen et al., 2007), strains $1662^{\mathrm{T}}$, 8484 and 18043 clearly represent a distinct genus from the $16 \mathrm{~S}$ rRNA gene sequence perspective, for which the name Chelonobacter gen. nov. is proposed. 16S rRNA gene sequence similarity between strain 17123 and the type strain of $[P$.$] testudinis was 95.6 \%$, indicating a genus-like relationship between these two strains.

The partial $r p o B$ gene sequence was determined according to Mollet et al. (1997) and covered the region 509-680 (Escherichia coli positions) of the deduced protein sequence as reported previously (Angen et al., 2003; Korczak et al., 2004). In addition to published primers, the forward PCR primer rpobfAp (GCAGTGAAAGAGTTCTTYGGTTC) was used for PCR amplification and DNA sequencing since the published primers did not result in amplification.
Sequencing was performed by Macrogen (Seoul, Korea). The GenBank accession numbers of the $r p o B$ gene sequences of strains 11321, 18043,8484, 17123, $4 \mathrm{n}$ and 770 are listed in Table 1 and Supplementary Fig. S1 (available in IJSEM Online). The $r p o B$ gene sequences of strains $266 / 6375,1662^{\mathrm{T}}, 10259,10977,11321,14061$, 14314, 15322 and 15875 were identical and only that of strain 11321 was deposited in GenBank. Strain 8484 was closely related to these sequences with $99.8 \%$ similarity. Strain HIM $768-4^{\mathrm{T}}$ of $[P$.] testudinis shared the published sequence for this strain (ATCC $33688^{\mathrm{T}}$; GenBank accession no. AY362972) and was closely related to strains $4 \mathrm{n}$ and 770 with similarities of 99.3 and $99.7 \%$, respectively. Strain 18043 was related to the Chelonobacter group with $95 \%$ similarity and to the other strains with $83-84 \%$ similarity. Strain 17123 was most closely related to the type strain of $[P$.] testudinis with $88 \%$ similarity. The lowest $r p o B$ gene sequence similarity within the Chelonobacter group was $94.7 \%$ between strains 18043 and 8484 (Supplementary Fig. S1, available in IJSEM Online). At the protein level, all 12 strains within the Chelonobacter group shared identical sequences. Also, the two strains $4 \mathrm{n}$ and 770 shared identical protein sequences with the type strain of $[P$.$] testudinis. In$ the phylogenetic analysis of $r p o B$ gene sequences, the published sequence of the type strain of $[P$.] testudinis was included as well as that of Pasteurella multocida, representing an outgroup (Supplementary Fig. S1). Strains 18043 and $1662^{\mathrm{T}}$, representing the novel species Chelonobacter oris gen. nov., sp. nov., as well as strain 17123, had the closest relationship to $[P$.] testudinis according to a BLASTN search of GenBank, indicating no other published sequences for these bacteria. The relatedness of the strains within the Chelonobacter group was confirmed by the $r p o B$ gene sequence analysis with a bootstrap support of $100 \%$ (Supplementary Fig. S1, available in IJSEM Online).

Previous studies with comparisons of the $r p o B$ gene sequence concluded that genera of the family Pasteurellaceae showed similarities above $85-88 \%$ at the nucleotide sequence level (Korczak et al., 2004; NørskovLauritsen et al., 2004). Observations based on rpoB gene sequence comparisons confirmed that 11 of the 12 unclassified isolates belong to a new genus, Chelonobacter, whereas the remaining isolate, strain 17123, was related to a genus-like group represented by [P.] testudinis.

The DNA G + C content of strain $1662^{\mathrm{T}}$ was $47.2 \mathrm{~mol} \%$, as determined by the Deutsche Sammlung von Mikroorganismen und Zellkulturen (DSMZ; Braunschweig, Germany) according to the procedure of Mesbah et al. (1989).

Classical phenotypic tests were performed as previously reported (Bisgaard et al., 1991). In addition, Diatabs (Rosco diagnostica) were used according to the manufacturer's protocol. Diatabs have been evaluated previously for phenotypic characterization within the family Pasteurellaceae (Angen et al., 2002). 
Table 1. Strains investigated in this study

\begin{tabular}{|c|c|c|c|c|c|}
\hline \multirow[t]{2}{*}{ Taxon } & \multicolumn{2}{|c|}{ GenBank accession no. } & \multirow[t]{2}{*}{ Source of isolation } & \multirow[t]{2}{*}{ Year of isolation } & \multirow[t]{2}{*}{ Disease associated with isolate } \\
\hline & $\begin{array}{l}\text { 16S rRNA gene } \\
\text { sequence }\end{array}$ & $r p o B$ gene sequence $\dagger$ & & & \\
\hline \multicolumn{6}{|l|}{ [Pasteurella] testudinis } \\
\hline $\begin{array}{l}\text { ATCC } 33688^{\mathrm{T}} \\
\left(=\text { HIM } 768-4^{\mathrm{T}}\right. \\
\left.=\text { UCD } 90-23-79 \mathrm{n}^{\mathrm{T}}\right)\end{array}$ & & AY362972 & Nares, Gopherus agassizi, USA & & \\
\hline $770^{*}$ & & EU331071 & Mouth, Gopherus agassizi, USA & & \\
\hline $4 n^{*}$ & & EU331072 & Nares, Gopherus agassizi, USA & & \\
\hline \multicolumn{6}{|l|}{ Chelonobacter oris } \\
\hline $1662^{\mathrm{T}}$ & EU331064 & id. EU331069 & Mouth, choanae, Testudo hermanni, Austria & 2007 & $\begin{array}{l}\text { Cachexy, soft carapace, redness of carapace } \\
\text { (suspicious for bacterial infection), apathy }\end{array}$ \\
\hline $266 / 6375$ & & id. EU331069 & Abscess, tortoise, Belgium & & \\
\hline 8484 & EU331065 & EU331068 & Mouth, choanae, Testudo hermanni, Austria & 2005 & $\begin{array}{l}\text { Vomitus, redness of carapace (suspicious for } \\
\text { bacterial infection), vesicles on nasal mucosa }\end{array}$ \\
\hline 0259 & & id. EU331069 & Mouth, Testudo hermanni, Austria & 2006 & 'Blocked' nose, respiratory sounds, cachexy \\
\hline 10977 & & id. EU331069 & Mouth, choanae, Testudo hermanni, Austria & 2006 & Apathy, respiratory sounds, hyperkeratosis \\
\hline 11321 & & EU331069 & Mouth, Testudo hermanni, Austria & 2006 & Lameness \\
\hline 14061 & & id. EU331069 & Conjunctiva, Testudo hermanni, Austria & 2006 & Infection of both eyes \\
\hline 14314 & & id. EU331069 & Mouth, choanae, Testudo hermanni, Austria & 2005 & $\begin{array}{l}\text { Apathy, tail injury, redness of carapace } \\
\text { (suspicious for bacterial infection) }\end{array}$ \\
\hline 15322 & & id. EU331069 & Mouth, Testudo hermanni, Austria & 2006 & Diarrhoea, cachexy \\
\hline 15875 & & id. EU331069 & Mouth, choanae, Testudo hermanni, Austria & 2005 & $\begin{array}{l}\text { Redness of carapace (suspicious for bacterial } \\
\text { infection) }\end{array}$ \\
\hline 18043 & EU331066 & EU331070 & Reptile, no further information, Austria & & No information \\
\hline \multicolumn{6}{|l|}{ Unclassified } \\
\hline 17123 & EU331067 & EU331073 & Skin, Trachemys scripta scripta, Austria & 2005 & Inflammation of skin \\
\hline
\end{tabular}

${ }^{\star}$ Received from K. P. Snipes, Department of Veterinary Microbiology, University of California, Davis, CA 95616, USA.

$\dagger$ id., DNA sequence identical to that of the accession number indicated. 


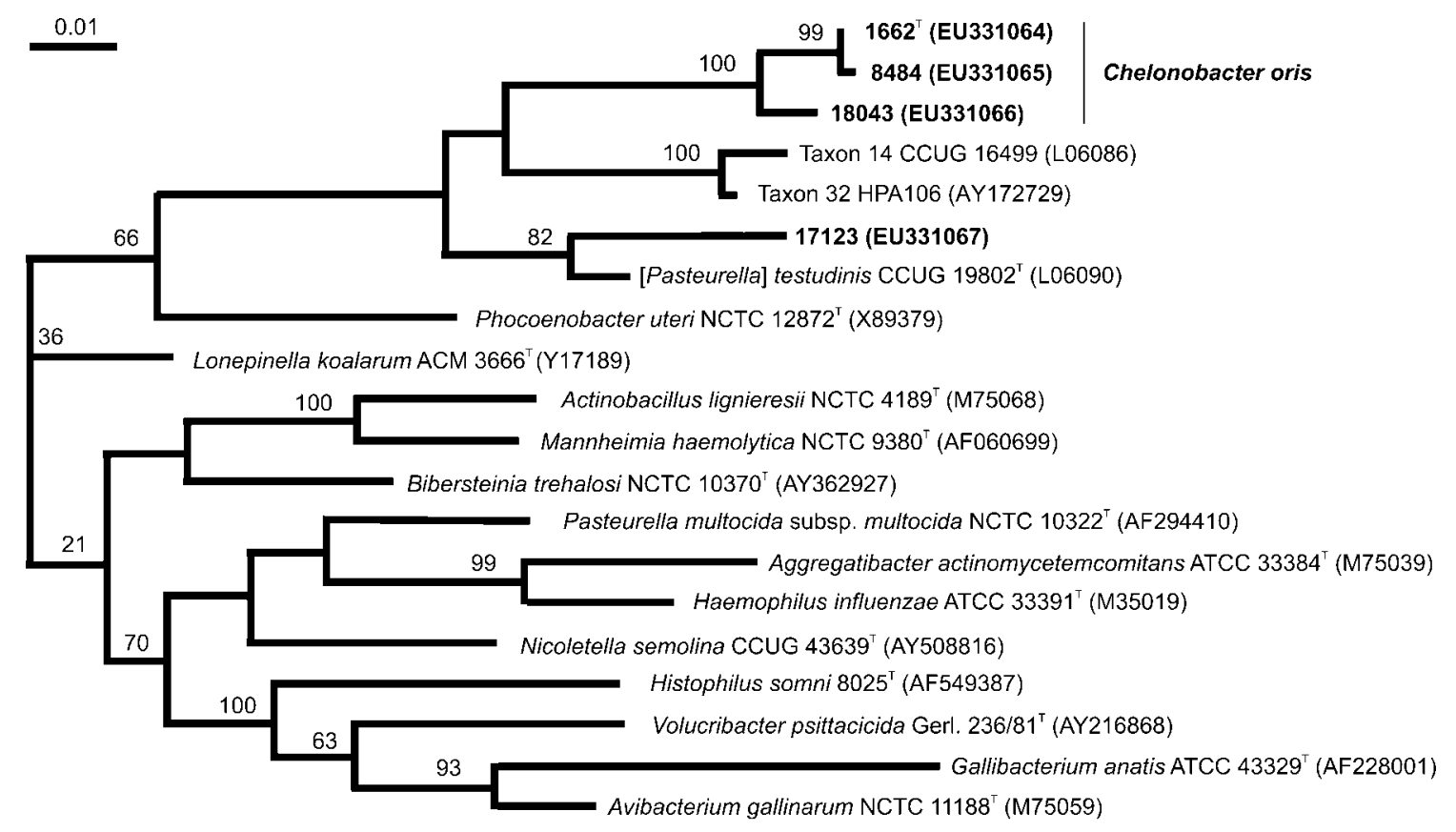

Fig. 1. Phylogenetic relationships between Chelonobacter oris gen. nov., sp. nov. and representative members of the family Pasteurellaceae based on maximum-likelihood analysis of 16S rRNA gene sequences. Support for monophyletic groups by bootstrap analysis is indicated as numbers out of 100 . The strains in bold have been sequenced in the present investigation. Bar, 0.01 evolutionary distance.

All isolates classified as Chelonobacter oris gen. nov., sp. nov. and unclassified strain 17123 stained Gram-negatively, were non-motile, pleomorphic rods (see Supplementary Fig. S2, available in IJSEM Online), were catalase- and oxidase-positive, and produced acid fermentatively from glucose without gas in Hugh and Leifson's medium. $\beta$ Haemolysis was observed with all strains when cultured on $5 \%$ bovine blood agar.

Phenotypic characteristics separating the strains investigated are given in Table 2 . The three reference strains of $[P$.] testudinis showed identical reaction patterns. The 12 unclassified strains could be distinguished from the reference strains on the basis of indole production, phosphatase and formation of acid from dulcitol and trehalose. The single $[P$.] testudinis-like strain, 17123, differed only from the type strain in trehalose and $\beta$ glucosidase (NPG) activities and all strains except 17123 were positive for aesculin hydrolysis. Strain 18043 could be distinguished from strains of Chelonobacter oris gen. nov., sp. nov. based on indole production. The 12 unclassified strains could be separated from Bisgaard's taxa 14 and 32 (Christensen et al., 2003) based on several characteristics, including $\beta$-haemolysis. At least two phenotypic characteristics separated the new genus from existing genera within the family Pasteurellaceae (Supplementary Table S1, available in IJSEM Online).

The results obtained from genotypic and phenotypic tests showed good correlation. The monophyly of the new genus proposed as Chelonobacter gen. nov. was clearly indicated by $16 \mathrm{~S}$ rRNA gene sequence analysis. Comparison of $r p o B$ gene sequences supported this, since members of other genera within the family Pasteurellaceae have been found to show relatedness values above $85-88 \%$ at the DNA level (Angen et al., 2003; Korczak et al. 2004; Nørskov-Lauritsen et al., 2004, Kuhnert et al., 2004). Furthermore, the proposed genus, Chelonobacter gen. nov., fulfils the

Table 2. Differential phenotypic characteristics of the strains investigated in this study

Taxa: 1, Chelonobacter oris gen. nov., sp. nov.; 2, [P.] testudinis UCD 90-23-79n $\mathrm{n}^{\mathrm{T}}$; 3, strain 17123 . + , Positive reaction within $1-2$ days; $(+)$, positive reaction within $3-14$ days; $\mathrm{w}$, weakly positive reaction; - , negative reaction after final reading.

\begin{tabular}{|lccc|}
\hline Characteristic & $\mathbf{1}$ & $\mathbf{2}$ & $\mathbf{3}$ \\
\hline Indole production & $-\star$ & + & + \\
Phosphatase & $\mathrm{w}^{\dagger}$ & - & - \\
Acid production from: & & & \\
$\quad$ Dulcitol & $+\ddagger$ & - & - \\
$\quad$ Trehalose & + & - & + \\
$\beta$-Glucosidase (NPG) & + & + & - \\
\hline
\end{tabular}

${ }^{\star}$ Reaction for strain 18043 was + .

$\dagger$ Reactions observed for strains 8484 and 10259 were + . $\ddagger$ Reaction for strain 18043 was $(+)$. 
suggested minimal standards for descriptions of members of the family Pasteurellaceae, including the number of strains investigated (Christensen et al., 2007). The authors desist from the reclassification of $[P$.] testudinis and the single isolate 17123 since more strains are needed to demonstrate possible divergence within this group.

The low diversity within the genus Chelonobacter gen. nov. indicates the presence of only one species, for which the name Chelonobacter oris gen. nov., sp. nov. is proposed. The highest genotypic and phenotypic diversity was observed between a group of ten strains, including the type strain, and strain 18043. Divergence was observed in only one phenotypic characteristic (indole production) and low genotypic divergence between strain 18043 and the other ten strains was found with respect to both $16 \mathrm{~S}$ rRNA and $r p o B$ gene sequences.

\section{Description of Chelonobacter gen. nov.}

Chelonobacter (Che.lo.no.bac'ter. Gr. n. chelone -es a tortoise; N.L. masc. n. bacter a rod; N.L. masc. n. Chelonobacter rod isolated from tortoise).

Members of the genus stain Gram-negatively and are nonmotile, pleomorphic rods that are catalase- and oxidasepositive and produce acid fermentatively from glucose without gas in Hugh and Leifson's medium. After $24 \mathrm{~h}$ aerobic incubation at $37{ }^{\circ} \mathrm{C}$, regular, slightly raised, circular colonies are formed with an entire margin surrounded by a zone of $\beta$-haemolysis. Positive for nitrate reduction and acid production from $(+)$-L-arabinose, dulcitol, $(-)$-Dmannitol, (-)-D-fructose, (+)-D-glucose, (+)-D-mannose, cellobiose, maltose, sucrose, trehalose and salicin. Positive for $\beta$-galactosidase (ONPG). Negative for X- and $\mathrm{V}$-factor requirement, urease, lysine decarboxylase, ornithine decarboxylase, pigment formation, $\alpha$-fucosidase, $\alpha$-galactosidase, $\alpha$-glucosidase (PNPG), $\beta$-glucuronidase (PGUA), $\alpha$-mannosidase and $\beta$-xylosidase (ONPX). Strains have been isolated from diseased tortoises and turtles. The type species is Chelonobacter oris sp. nov.

\section{Description of Chelonobacter oris sp. nov.}

Chelonobacter oris (o'ris. L. n. os oris mouth; L. gen. n. oris of/from the mouth).

Colony and cellular morphologies are as given in the genus description. The surface of the colonies is smooth, shiny and opaque. Colonies are between 1.0 and $1.5 \mathrm{~mm}$ in diameter. The consistency of the colonies is unguent-like and adherence to the agar is not observed. In addition to the phenotypic characteristics given in the genus description, acid is produced from $(+)$-D-arabitol, $(-)$-D-ribose, $(+)$-D-xylose, (-)-D-fucose, raffinose and dextrin. Positive for aesculin hydrolysis and $\beta$-glucosidase (NPG). Negative for citrate utilization and production of acid from adonitol, (-)-D-sorbitol, lactose, melibiose and inulin. The type strain is indole-negative; a single isolate (18043) is indole-positive.
The type strain is $1662^{\mathrm{T}}\left(=\right.$ CCUG $\left.55632^{\mathrm{T}}=\mathrm{DSM} 21392^{\mathrm{T}}\right)$, isolated from a diseased tortoise. The DNA G+C content of the type strain is $47.2 \mathrm{~mol} \%$.

\section{Acknowledgements}

Tony Bønnelycke and Katrine Madsen are thanked for excellent technical assistance. Dr Sabine Gronow, DSMZ, is thanked for the photomicrograph of strain $1662^{\mathrm{T}}$. We would like to thank Dr Jean Euzéby, Laboratoire de Bactériologie, École Nationale Vétérinaire, Toulouse, France, for help with the Latin name. The project was financed by the Danish Natural Science Research Council grant no. 272-06-0584.

\section{References}

Altschul, S. F., Madden, T. L., Schäffer, A. A., Zhang, J., Zhang, Z., Miller, W. \& Lipman, D. J. (1997). Gapped BLAST and PSI-BLAST: a new generation of protein database search programs. Nucleic Acids Res 25, 3389-3402.

Angen, Ø., Ahrens, P. \& Bisgaard, M. (2002). Phenotypic and genotypic characterization of Mannheimia (Pasteurella) haemolyticalike strains isolated from diseased animals in Denmark. Vet Microbiol 84, 103-114.

Angen, Ø., Ahrens, P., Kuhnert, P., Christensen, H. \& Mutters, R. (2003). Proposal of Histophilus somni gen. nov., sp. nov. for the three species incertae sedis 'Haemophilus somnus', 'Haemophilus agni' and 'Histophilus ovis'. Int J Syst Evol Microbiol 53, 1449-1456.

Benson, D. A., Karsch-Mizrachi, I., Lipman, D. J., Ostell, J. \& Wheeler, D. L. (2006). GenBank. Nucleic Acids Res 34, D16-D20.

Bisgaard, M., Houghton, S. B., Mutters, R. \& Stenzel, A. (1991). Reclassification of German, British and Dutch isolates of so-called Pasteurella multocida obtained from pneumonic calf lungs. Vet Microbiol 26, 115-124.

Christensen, H., Bisgaard, M., Angen, Ø. \& Olsen, J. E. (2002). Final classification of Bisgaard taxon 9 as Actinobacillus arthritidis sp. nov. and recognition of a novel genomospecies for equine strains of Actinobacillus lignieresii. Int J Syst Evol Microbiol 52, 1239-1246.

Christensen, H., Foster, G., Christensen, J. P., Pennycott, T., Olsen, J. E. \& Bisgaard, M. (2003). Phylogenetic analysis by $16 \mathrm{~S}$ rDNA gene sequence comparison of avian taxa of Bisgaard and characterization and description of two new taxa of Pasteurellaceae. J Appl Microbiol 95, 354-363.

Christensen, H., Kuhnert, P., Busse, H. J., Frederiksen, W. C. \& Bisgaard, M. (2007). Proposed minimal standards for the description of genera, species and subspecies of the Pasteurellaceae. Int J Syst Evol Microbiol 57, 166-178.

Dewhirst, F. E., Paster, B. J., Olsen, I. \& Fraser, G. J. (1993). Phylogeny of the Pasteurellaceae as determined by comparison of 16S ribosomal ribonucleic acid sequences. Zentralbl Bakteriol 279, 35-44.

Felsenstein, J. (1995). PHYLIP (phylogeny inference package) version 3.57c. Distributed by the author. Department of Genome Sciences, University of Washington, Seattle, USA.

Jang, S. S. \& Biberstein, E. L. (1991). Observations on the occurrence of Pasteurella testudinis in clinical specimens from animals. $J$ Vet Diagn Invest 3, 174-176.

Korczak, B., Christensen, H., Emler, S., Frey, J. \& Kuhnert, P. (2004). Phylogeny of the family Pasteurellaceae based on rpoB sequences. Int $J$ Syst Evol Microbiol 54, 1393-1399.

Kuhnert, P., Korczak, B., Falsen, E., Straub, R., Hoops, A., Boerlin, P., Frey, J. \& Mutters, R. (2004). Nicoletella semolina gen. nov., sp nov., a 
new member of Pasteurellaceae isolated from horses with airway disease. J Clin Microbiol 42, 5542-5548.

Mesbah, M., Premachandran, U. \& Whitman, W. B. (1989). Precise measurement of the $\mathrm{G}+\mathrm{C}$ content of deoxyribonucleic acid by highperformance liquid chromatography. Int J Syst Bacteriol 39, 159-167.

Mollet, C., Drancourt, M. \& Raoult, D. (1997). rpoB sequence analysis as a novel basis for bacterial identification. Mol Microbiol 26, 1005-1011.

Mutters, R., Ihm, P., Pohl, S., Frederiksen, W. \& Mannheim, W. (1985). Reclassification of the genus Pasteurella Trevisan 1887 on the basis of deoxyribonucleic acid homology, with proposals for the new species Pasteurella dagmatis, Pasteurella canis, Pasteurella stomatis, Pasteurella anatis, and Pasteurella langaa. Int J Syst Bacteriol 35, 309-322.

Nørskov-Lauritsen, N., Christensen, H., Okkels, H., Kilian, M. \& Bruun, B. (2004). Delineation of the genus Actinobacillus by comparison of partial infB sequences. Int J Syst Evol Microbiol 54, 635-644.
Olsen, G. J., Matsuda, H., Hagstrom, R. \& Overbeek, R. (1994). fastDNAml: a tool for construction of phylogenetic trees of DNA sequences using maximum likelihood. Comput Appl Biosci 10, 41-48.

Rice, P., Longden, I. \& Bleasby, A. (2000). EMBOSS: the European molecular biology open software suite. Trends Genet 16, 276-277.

Snipes, K. P. \& Biberstein, E. L. (1982). Pasteurella testudinis sp. nov.: a parasite of desert tortoises (Gopherus agassizi). Int J Syst Bacteriol 32, 201-210.

Snipes, K. P., Biberstein, E. L. \& Fowler, M. E. (1980). A Pasteurella $\mathrm{sp}$. associated with respiratory disease in captive desert tortoises. $J \mathrm{Am}$ Vet Med Assoc 177, 804-807.

Thompson, J. D., Gibson, T. J., Plewniak, F., Jeanmougin, F. \& Higgins, D. G. (1997). The CLUSTAL_X windows interface: flexible strategies for multiple sequence alignment aided by quality analysis tools. Nucleic Acids Res 25, 4876-4882. 